\title{
Time-Dependent Alterations in mRNA Expression of Brain Neuropeptides Regulating Energy Balance and Hypothalamo-Pituitary-Adrenal Activity after Withdrawal from Intermittent Morphine Treatment
}

\author{
Hani Houshyar, Sotara Manalo, and Mary F. Dallman \\ Department of Physiology and Neuroscience Program, University of California, San Francisco, San Francisco, California 94143-0444
}

\begin{abstract}
Chronic stressors alter brain function and may leave traces after their relief. We used intermittent morphine treatment to examine the relationships between stress-induced changes in energy balance and hypothalamo-pituitary-adrenal (HPA) activity and the recovery thereafter. We studied the effects of morphine injections on energy balance, hormones and fat stores, brain neuropeptide expression, and the ACTH and corticosterone responses to restraint $12 \mathrm{hr}$ after the final injection and $8 \mathrm{~d}$ later during recovery. Weight gain, food intake, and caloric efficiency decreased at morphine onset, and these were maintained throughout the morphine injections. At $12 \mathrm{hr}$, fat stores, leptin, insulin, and testosterone concentrations were reduced. Subsequently, body weight gain and food intake increased and caloric efficiency was above control during the final days. By the eighth recovery day, fat stores and peripheral hormones were no longer depressed. At $12 \mathrm{hr}$, an over-response of CRF mRNA to restraint occurred in the hypothalamus, similar to the facilitated ACTH and corticosterone responses. On day 8, the hypothalamic CRF mRNA response to restraint was still facilitated, opposite to inhibited ACTH responses. Hypothalamic CRF mRNA correlated highly with mesenteric fat weight in morphine-treated rats. We conclude that there is a prolonged recovery from chronic stressors involving interrelated changes in energy balance and HPA activity. Nonetheless, $8 \mathrm{~d}$ after withdrawal from morphine, rats still display facilitated central stress responses, similar to the HPA symptoms described in posttraumatic stress disorder patients. Repeated partial withdrawal associated with intermittent morphine treatment, compounded by complete withdrawal associated with termination of the treatment, is likely required for these metabolic and HPA derangements.
\end{abstract}

Key words: AVP; CRF; dependence; energy balance; HPA axis; metabolism; morphine; NPY; opioid; POMC; PTSD; stress; withdrawal

\section{Introduction}

Chronic stressors appear to engage a chronic stress response network in the brain that involves the neuromodulator corticotropin-releasing factor (CRF) (Schulkin et al., 1994; Goeders, 2002; Dallman et al., 2003b). This network causes changes in behavioral, neuroendocrine, and metabolic outputs, such that, during a chronic stressor, fear- and anxiety-like behaviors are increased, hypothalamo-pituitary-adrenal (HPA) responses to novel stimuli are augmented, and typically ponderal growth stops and food intake (FI) and caloric efficiency (CE) are reduced (Dallman and Bhatnagar, 2001). We reported previously that, as with cocaine and other street drugs (Shalev et al., 2002), injections of morphine in escalating doses at $12 \mathrm{hr}$ intervals serve as a chronic stressor (Houshyar et al., 2001a,b, 2003a). The effects of intermittent morphine treatment are in contrast to the effects of morphine dependence induced by constant morphine exposure

Received April 29, 2004; revised Aug. 11, 2004; accepted Aug. 11, 2004.

This work was supported in part by National Institutes of Health Grants DK28172 and F32-DA14143 (H.H.).

Correspondence should be addressed to Dr. Hani Houshyar, Department of Physiology, University of California,

San Francisco, San Francisco, CA 94143-0444. E-mail: hani@itsa.ucsf.edu.

DOI:10.1523/JNEUROSCI.1641-04.2004

Copyright $\odot 2004$ Society for Neuroscience $\quad$ 0270-6474/04/249414-11\$15.00/0 and are likely a result of the repeated partial withdrawal associated with intermittent drug administration.

After the application of moderate-intensity chronic or highintensity acute stressors is completed, there is a slow process of apparent recovery from recruitment of the stress response network of the brain. Behavioral abnormalities persist for at least $16 \mathrm{~d}$ but not for $64 \mathrm{~d}$ after withdrawal from drugs (Shalev et al., 2002). HPA responses to new stimuli tend to be markedly reduced for long periods after the end of a sufficiently intense single or chronic stressor (van Dijken et al., 1993; Schmidt et al., 1996; Houshyar et al., 2001a,b). We recently showed that $4 \mathrm{~d}$ of intermittent morphine injections, although sufficient to induce facilitated HPA responses to new stimuli, was not sufficient to induce robustly the typical delayed characteristics of an intense chronic stressor, and, therefore, we did not examine the long-term changes in the brains of such rats (Houshyar et al., 2003a).

There is a tight correlation between metabolic status and HPA activity during periods of chronic stress (Dallman et al., 2004). During chronic stress, corticosterone acts peripherally on metabolism to reduce activity in the HPA axis (Dallman et al., 2003a). Although the precise signal is not identified, mesenteric fat appears to be a good surrogate for the signal that informs the paraventricular nucleus (PVN) CRF cells that there are sufficient en- 
Table 1. Experimental groups used in the current study

\begin{tabular}{llll}
\hline Experiment & Treatment duration & Withdrawal duration & Stress groups \\
\hline 1 & $8 \mathrm{~d}$ morphine & $12 \mathrm{hr}$ withdrawal & Basal, tail nick, restraint \\
& $8 \mathrm{~d}$ vehicle & $12 \mathrm{hr}$ control & Basal, tail nick, restraint \\
2 & $8 \mathrm{~d}$ morphine $+8 \mathrm{~d}$ vehicle & $8 \mathrm{~d}$ withdrawal & Basal, tail nick, restraint \\
& $16 \mathrm{~d}$ vehicle & $8 \mathrm{~d}$ control & Basal, tail nick, restraint \\
\hline
\end{tabular}

$n=6$ rats per group.

ergy stores in the abdomen (Dallman et al., 2003b). Because $4 \mathrm{~d}$ of morphine did not induce the typical delayed metabolic and HPA characteristics of chronic stressors, we supposed that a longer and more intense morphine treatment was required. We hoped to gain additional insight into the relationships between stressinduced changes in metabolic state and HPA activity and to delineate changes during the recovery process.

Here, we tested the effects of $8 \mathrm{~d}$ of escalating doses of morphine, both $12 \mathrm{hr}$ after the final morphine injection and $8 \mathrm{~d}$ later, during recovery, on energy balance and responses to a novel acute stressor in male rats (Houshyar et al., 2003b). In addition to metabolic and hormonal responses, we also determined CRF expression in four brain sites and measured vasopressin expression in the hypothalamic paraventricular nuclei, as well as the expression of feeding-associated peptides, neuropeptide Y (NPY) and pro-opiomelanocortin (POMC), in the arcuate nuclei.

\section{Materials and Methods}

Subjects. Male Sprague Dawley rats $60 \mathrm{~d}$ of age (Bantin and Kingman, Gilroy, CA), weighing 260-300 gm at the beginning of experiments, were used for these studies. Rats were housed individually in hanging wire cages with ad libitum access to food (Purina Rodent Chow, Diet 5008; Purina Mills, St. Louis, MO) and water. They were housed in a room maintained under standard conditions of light (lights on, 7:00 A.M. to 7:00 P.M.) and temperature $\left(22 \pm 2^{\circ} \mathrm{C}\right)$. Experiments were initiated shortly after lights were turned on, between 7:00 A.M. and 7:30 A.M. All of the experimental procedures were approved by the Committee on Animal Research, University of California, San Francisco, and were performed according to the Guide for the Care and Use of Laboratory Animals of the Institute for Laboratory Animal Research, Commission on Life Sciences, National Research Council (Department of Health, Education and Welfare).

Morphine dependence and withdrawal. On the basis of previous studies, morphine dependence was induced by subcutaneous injections of morphine (National Institute of Drug Abuse) twice daily (7:00 A.M. and 7:00 P.M.) for $8 \mathrm{~d}$ with increasing doses (10, 20, 30, 40, 50, 60, 70, and 80 $\mathrm{mg} / \mathrm{kg}$ per injection) on each day (Houshyar et al., 2001a,b, 2003a,b). After termination of the morphine treatment, rats received either one injection of saline $12 \mathrm{hr}$ after their final morphine injection (12 hr withdrawal) or they continued to receive injections of saline twice daily for 8 additional d ( $8 \mathrm{~d}$ withdrawal) (Table 1). As a control, for each of the above morphine treatment groups, a group of rats was treated with the vehicle saline twice daily for either 8 ( $12 \mathrm{hr}$ control) or 16 ( $8 \mathrm{~d}$ control) consecutive days. Within each of the above treatment groups, rats were decapitated as follows: (1) at 7:00 A.M. (time, 0 min) under basal conditions, (2) at 11:00 A.M. (time, $240 \mathrm{~min}$ ) after exposure to repeated tail bleeding, or (3) at 11:00 A.M. (time, $240 \mathrm{~min}$ ) after exposure to $30 \mathrm{~min}$ of restraint stress and repeated tail bleeding.

Acute stress: tail bleeding and restraint. In the animal room, on the final experimental day, one-third of the rats within each group were immediately decapitated under basal conditions (time, $0 \mathrm{~min}$ ). The other twothirds of the rats within each treatment group were exposed to tail bleeding $\pm 30 \mathrm{~min}$ restraint stress. For tail bleeding, rats were removed from their home cages, and, within $2 \mathrm{~min}$, a blood sample (time 0 ) was collected from a cut $(\sim 1 \mathrm{~mm})$ made across the tip of the tail. These samples were considered to reflect basal conditions. Rats in the "tail nick only" group were immediately returned to their home cages, whereas rats in the "tail nick + restraint" group were placed in restraint tubes. Exposure to restraint was terminated $30 \mathrm{~min}$ after initiation of this stressor, at which time rats were returned to their home cages. In both groups, blood was collected by gently dislodging the formed clot at 15, 30, 60,90 , and 120 min after the initial tail nick. Samples of $240 \mu$ l were collected using heparinized Natelson blood-collecting tubes (Fisher Scientific, Pittsburgh, PA) and kept at $4^{\circ} \mathrm{C}$ until centrifuged in the cold; plasma was aliquoted and frozen until analysis.

Physiological measures. Body weight (BW) and FI were recorded twice daily at 7:00 A.M. and 7:00 P.M. during the times of drug (vehiclemorphine) administration. At the end of experiments, rats were decapitated, and trunk blood was collected for determination of hormone concentrations. In addition, epidydimal, mesenteric, perirenal, and subcutaneous white adipose tissue (WAT), as well as adrenals and thymuses, were dissected, cleaned, and weighed.

Radioimmunoassays. All of the plasma hormone concentrations were measured using radioimmunoassays (RIAs). Plasma corticosterone and testosterone concentrations were measured using RIA kits purchased from MP Biomedicals (Irvine, CA). RIA kits for determination of plasma insulin and leptin concentrations were purchased from Linco Research (St. Charles, MO). Plasma ACTH concentrations were determined by an RIA that used a specific antiserum, generously donated by Dr. William Engeland (University of Minnesota, Minneapolis, MN) at a dilution of 1:120,000 and $\left[{ }^{125} \mathrm{I}\right]$ ACTH (DiaSorin, Stillwater, MN) as labeled trace.

In situ hybridization. Brains were sectioned at $14 \mu \mathrm{m}$ in the coronal plane, and sections were collected onto Superfrost Plus microscope slides (Fisher Scientific) and were stored at $-80^{\circ} \mathrm{C}$ until additional processing. In situ hybridization analyses for arginine vasopressin (AVP), CRF, POMC, and NPY were conducted using techniques described previously (Dallman et al., 1999; Bell et al., 2000; Viau et al., 2001; Houshyar et al., 2003a). A one-in-six series of $14 \mu \mathrm{m}$ sections was stained with cresyl violet, and sequential one-in-six series of tissue were incubated with radiolabeled RNA probes complementary to mRNAs for AVP, CRF, POMC, and NPY.

Sections were fixed with $4 \%$ paraformaldehyde for $5 \mathrm{~min}$ and then washed with PBS for $2 \mathrm{~min}$ on ice. Then, sections were acetylated for 10 $\min (0.25 \%$ acetic anhydride in $0.1 \mathrm{M}$ triethanolamine- $0.9 \% \mathrm{NaCl}, \mathrm{pH}$ $8.0)$ at room temperature. Sections were then rinsed with $2 \times$ SSC, transferred through $70 \%$ ( $2 \mathrm{~min}$ ), 95\% (2 $\mathrm{min}$ ), and 100\% (2 min) ethanol, $100 \%$ chloroform ( $5 \mathrm{~min}$ ), and $95 \%$ ethanol ( $2 \mathrm{~min}$ ), and dried. Hybridization histochemical localization of AVP and CRF mRNAs was performed using a probe transcribed from a $230 \mathrm{bp}$ cDNA fragment encoding the vasopressin-specific $3^{\prime}$ end (exon C) of AVP (a gift from Dr. D. Richter, University of Hamburg, Hamburg, Germany) and a probe transcribed from a full-length $(1.2 \mathrm{~kb}) \mathrm{cDNA}$ encoding CRF mRNA (courtesy of Dr. K. Mayo, Northwestern University, Evanston, IL), respectively. The NPY probe was provided by Dr. M. W. Schwartz (University of Washington, Seattle, WA), and the POMC probe used was a 45 base cDNA oligomer (Dallman et al., 1999). The probes were labeled in a reaction mixture consisting of $1 \mu \mathrm{g}$ of linearized plasmid, $5 \times$ transcription buffer (Promega, Madison, WI), $5 \mu \mathrm{Ci}$ of $\left[{ }^{33} \mathrm{P}\right] \mathrm{rUTP}$, and $10 \mathrm{~mm}$ each of ATP, CTP, and GTP, $100 \mathrm{~mm}$ dithiothreitol, $40 \mathrm{U}$ of RNase inhibitor, and $30 \mathrm{U}$ of polymerase. The reaction was incubated for $2 \mathrm{hr}$ at $37^{\circ} \mathrm{C}$ and treated with DNase I for $15 \mathrm{~min}$ at $37^{\circ} \mathrm{C}$. Thereafter, the probe was separated from unincorporated nucleotides over a Micro Bio-Spin column (Bio-Rad, Hercules, CA). The probe was diluted in hybridization buffer, and $100 \mu$ l of diluted probe was applied to each slide to yield $\sim 2 \times$ $10^{6} \mathrm{cpm}$ of labeled probe per slide. Slides were then coverslipped and incubated overnight at $55^{\circ} \mathrm{C}$. The next day, slides were dipped in $2 \times$ SCC to remove the coverslips. Thereafter, slides were washed with RNase A at $37^{\circ} \mathrm{C}$ for $30 \mathrm{~min}$, followed by a wash in RNase A buffer (consisting of $1 \mathrm{M}$ Tris, $5 \mathrm{M} \mathrm{NaCl}$, and $0.5 \mathrm{M}$ EDTA) without any RNase A for an additional $30 \mathrm{~min}$ at $37^{\circ} \mathrm{C}$. Next, slides were washed in $1 \times \mathrm{SSC}$ at room temperature, followed by a wash in $0.5 \times \mathrm{SSC}$ for $30 \mathrm{~min}$ at $60^{\circ} \mathrm{C}$. Finally, slides were dehydrated in 70,95 , and $100 \%$ ethanol for 2 min each and air dried. 
Slides were then exposed to Hyperfilm MP (Amersham Biosciences, Buckinghamshire, UK) for $6 \mathrm{hr}$ (AVP), $2 \mathrm{~d}$ (CRF in PVN), $6 \mathrm{~d}$ [CRF in the central nucleus of the amygdala (CeA), Barrington's nucleus, and the bed nucleus of the stria terminalis (BNST)], or $16 \mathrm{hr}$ (POMC and NPY). Subsequently, slides were coated with Kodak NTB2 liquid autoradiographic emulsion (diluted 1:1; Eastman Kodak, Rochester, NY) and exposed at $4^{\circ} \mathrm{C}$ in the dark for $18 \mathrm{hr}(\mathrm{AVP}), 6 \mathrm{~d}$ (CRF in PVN), $18 \mathrm{~d}$ (CRF in CeA, Barrington's nucleus, and BNST), or $2 \mathrm{~d}$ (NPY and POMC). Emulsion-dipped slides were developed with Kodak D-19 for 5 min, briefly rinsed in distilled water for $15 \mathrm{sec}$, fixed in Kodak fixer for $5 \mathrm{~min}$, and then washed in running water for $45 \mathrm{~min}$, all at room temperature. Slides were subsequently counterstained with cresyl violet, dehydrated in graded series of alcohol, placed in xylene, and coverslipped with Permount (Fisher Scientific). All of the sections within the same brain region from control and experimental rats were hybridized at the same time.

In analyzing AVP and CRF hybridization in the PVN, we used three sections spanning the midportion of the nucleus for each animal (bregma, -1.8 to 2.1). Medial parvocellular AVP mRNA containing cells in the PVN were differentiated histologically from magnocellular AVP mRNA containing cells on the basis of their overall smaller size, their relatively low level of AVP expression, and their small dense-staining nuclei. CRF hybridization in the central nucleus of the amygdala, Barrington's nucleus, and BNST also included three sections per probe (amygdala, bregma, -2.5 to -2.8 ; Barrington's nucleus, bregma, -9.6 to -9.8 ; BNST, bregma, 0.2 to $-0.26 \mathrm{~mm}$ ). NPY and POMC hybridization in arcuate nucleus of the hypothalamus (ARC) included nine sections per probe, with three sections each representing anterior (bregma, -2.8), medial (at the level of the dorsomedial nucleus; bregma, -3.3 ), and posterior (bregma, -3.8 ) ARC. Semiquantitative densitometric analyses of the relative level of AVP, CRF, NPY, and POMC were performed using Macintosh-driven NIH Image software (version 1.61). This was assisted by landmarks made apparent with the cresyl violet counterstaining. Optical density measurements in individual rats were determined from averaged readings of three sections and corrected for background. Analyses were performed blind to the identification of any group.

Data analysis. BW, FI, and CE data are only displayed for experiment 2 ( $8 \mathrm{~d}$ of morphine treatment followed by $8 \mathrm{~d}$ of morphine withdrawal), because the treatments and findings within the first $8 \mathrm{~d}$ of the experiment were similar between the two experimental groups. CE was calculated using the following formula: grams of body weight gained divided by calories ingested. BW, FI, and CE were analyzed by one-way ANOVA with time (days) as the repeated measure and treatment as the main factor. Tukey's honestly significant difference (HSD) test was used to assess the effect of treatment within each experimental day (days 1-16) on BW, FI, and CE. Organ and fat depot weights, as well as trunk plasma hormone concentrations, were similar between the "basal," "tail nick," and "restraint" groups within each treatment group; therefore, the data across these groups were combined. Organ and fat depot weights, as well as trunk hormone concentrations, were analyzed across experiments by two-way ANOVA with treatment (vehicle and morphine) and withdrawal duration ( $12 \mathrm{hr}$ and $8 \mathrm{~d}$ ) as the main factors, and were analyzed within experiments by one-way ANOVA with treatment as the main factor. ACTH and corticosterone data were analyzed by two-way ANOVA with time (minutes) as the repeated measure, and treatment and withdrawal duration as the main factors. As appropriate, a one-way ANOVA for repeated measures was used to examine the effect of treatment, and Tukey's HSD test was used to assess the effect of treatment at each particular time point $(0,15,30,60,90$, and $120 \mathrm{~min})$. Hybridization signals for CRF mRNA in the PVN were different between tail nick alone ("control") and tail nick + restraint ("stress") groups; therefore, the data are presented separately. A two-way ANOVA with treatment and stress as main factors was used to analyze the hybridization data for CRF mRNA in the PVN. Post hoc analysis was performed using Tukey's HSD test. Hybridization signals of CRF in the amygdala, Barrington's nucleus, and BNST, as well as signals of AVP, NPY, and POMC, were similar between the tail nick alone and tail nick + restraint groups; therefore, the data from these groups were combined. The hybridization data for these transcripts were analyzed by one-way ANOVA with treatment (vehicle and morphine) as the main factor. All of the data are presented as mean \pm

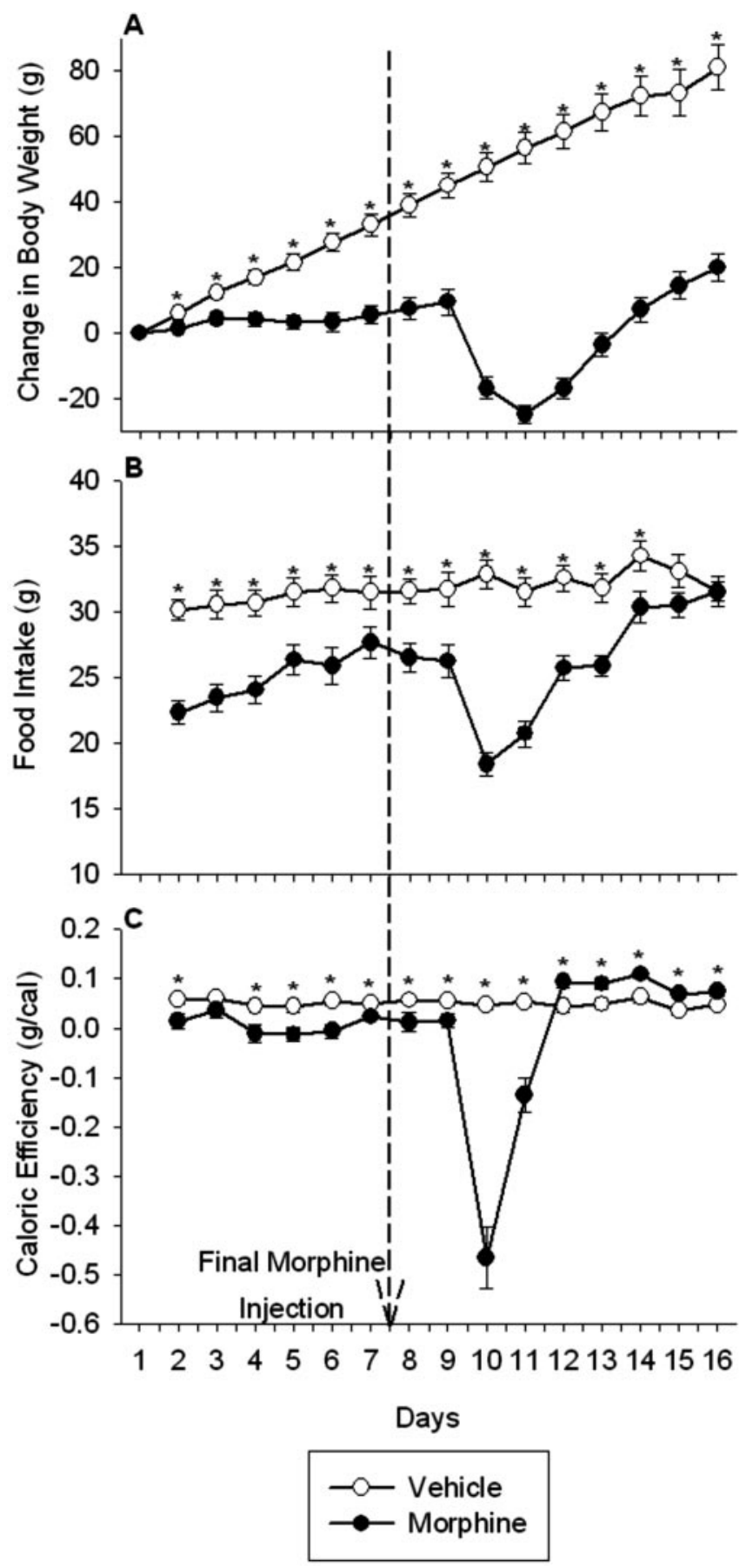

Figure 1. Intermittent morphine treatment and withdrawal from morphine reduced body weight gain $(A)$, food intake $(B)$, and caloric efficiency ( $O$ ). Rats received injections twice daily of morphine (10-80 mg/kg, s.c.) for 8 consecutive days, followed by $8 \mathrm{~d}$ of saline injections twice daily. The control group was treated twice daily with the vehicle saline throughout. Measurements of body weight and food intake were made every $12 \mathrm{hr}$, although body weight gain, food intake, and caloric efficiency are reported once daily in the morning. The dashed line indicates the time of final morphine injection. The results are expressed as means \pm SEM ( $n=$ 18 rats per group). ${ }^{*} p<0.05$ indicates significant effect of morphine versus saline treatment.

SEM. All of the statistical analyses were performed using Statistica (version 5.0; StatSoft, Tulsa, OK).

\section{Results}

Energy balance

Body weight

Administration of escalating doses of morphine twice daily for 8 consecutive d significantly reduced body weight gain compared 
Table 2. Effects of administration twice daily of escalating doses of morphine for 8 consecutive days during early (12 $\mathrm{hr}$ ) and late $(8 \mathrm{~d})$ withdrawal on relative white adipose depot weights

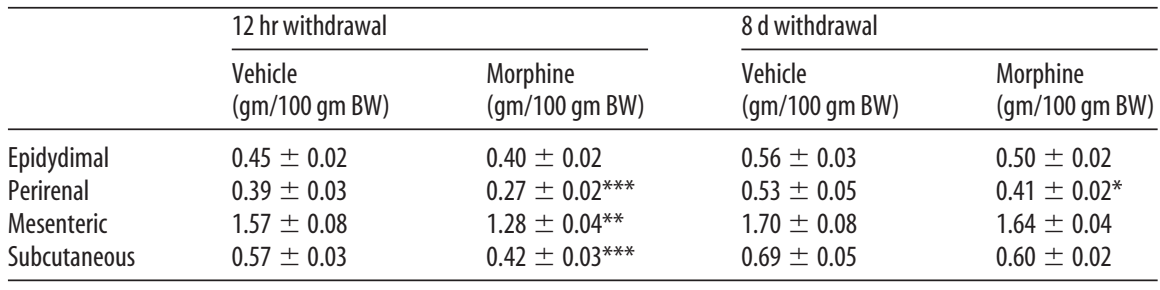

Values represent the mean \pm SEM of 18 rats per group. Vehicle versus morphine treated: ${ }^{*} p<0.05 ;{ }^{* *} p<0.01 ;{ }^{* * *} p<0.001$. weight gain in morphine-treated rats $(8.9 \pm 0.5 \mathrm{gm} / \mathrm{d})$ was nearly double that observed in vehicle-treated controls $(4.9 \pm 0.5 \mathrm{gm} / \mathrm{d})\left(F_{(1,34)}=3.9 ; p<\right.$ $0.0001)$.

\section{Food intake}

Food intake was significantly reduced in morphine-treated compared with vehicletreated rats (treatment, $F_{(1,34)}=28.8, p<$ 0.0001 ; time, $F_{(14,476)}=15.31, p<0.0001$; treatment $\times$ time, $F_{(14,476)}=10.4, p<$
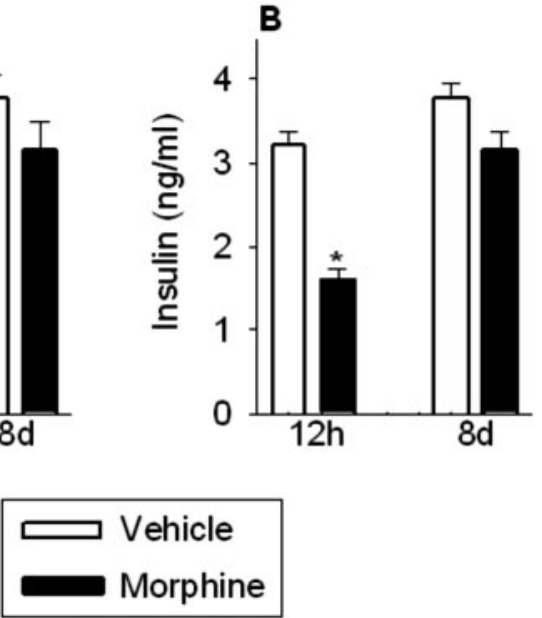

Figure 2. Plasma leptin $(A)$ and insulin $(B)$ concentrations were reduced in morphinetreated rats $12 \mathrm{hr}$ after the final morphine injection but had recovered $8 \mathrm{~d}$ later. The results are expressed as means \pm SEM ( $n=18$ rats per group). ${ }^{*} p<0.05$ indicates significant effect of morphine versus saline treatment.

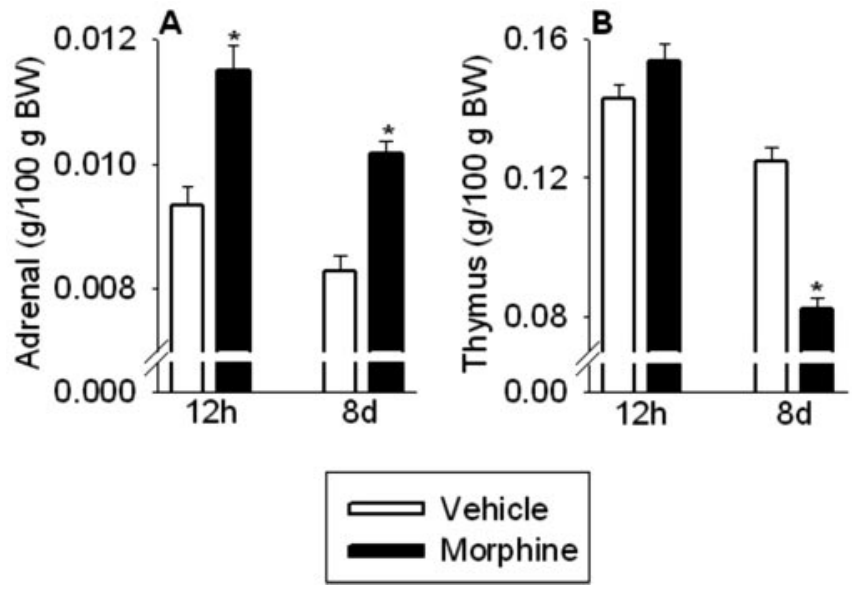

Figure 3. Adrenal weight $(A)$ was increased in morphine-treated rats $12 \mathrm{hr}$ and $8 \mathrm{~d}$ after the last injection, whereas thymus weight $(B)$ was decreased in morphine-treated rats $8 \mathrm{~d}$ after the final injection, but was normal $12 \mathrm{hr}$ after the final morphine injection. The results are expressed as means \pm SEM ( $n=18$ rats per group). ${ }^{*} p<0.05$ indicates significant effect of morphine versus saline treatment.

with vehicle-treated controls (treatment, $F_{(1,34)}=28.5, p<$ 0.0001 ; time, $F_{(14,476)}=85.6, p<0.0001$; treatment $\times$ time, $\left.F_{(14,476)}=37.2, p<0.0001\right)$ (Fig. $1 A$ ). Cessation of morphine treatment induced a significant $(p<0.0001)$ decrease in body weight during the major withdrawal period. Maximum weight loss was observed $2 \mathrm{~d}$ after the final morphine injection. However, subsequent to this maximal decrease in body weight, the rate of
0.0001) (Fig. $1 B$ ). Importantly, the decrease in food intake occurred only during the dark, but not the light, period [average food intake during the light period, vehicle, $9.0 \pm 0.3 \mathrm{gm}$; morphine, $9.7 \pm 0.5$, NS; average food intake during the dark period, vehicle, $22.7 \pm 0.3 \mathrm{gm}$; morphine, $16.2 \pm 0.8\left(F_{(1,34)}=7.3 ; p<\right.$ $0.0001)]$. In addition, after the last of the repeated morphine injections, there was an additional dramatic decrease $(p<$ 0.0001 ) in food intake that occurred during both the light and the dark cycles, maximal during $36 \mathrm{hr}$ after the final morphine injection, from which rats did not fully recover until the final $2 \mathrm{~d}$ of treatment.

\section{Caloric efficiency}

Caloric efficiency was significantly reduced in morphine-treated compared with vehicle-treated rats during the drug treatment (treatment, $F_{(1,34)}=24.7, p<0.0001$; time, $F_{(7,238)}=2.2, p<$ 0.05 ; treatment $\times$ time, $\left.F_{(7,238)}=0.9, \mathrm{NS}\right)($ Fig. $1 C)$. In addition, termination of repeated morphine treatment precipitated an additional decrease $(p<0.0001)$ in caloric efficiency, maximal during $36 \mathrm{hr}$ after the final morphine injection. Subsequently, however, caloric efficiency in morphine-treated rats rebounded to levels significantly above those observed in control rats and was maintained at this elevated level throughout the recovery period.

\section{White fat depot weights}

Morphine dependence and withdrawal decreased epidydimal (treatment, $F_{(1,68)}=6.8, p<0.05$; withdrawal, $F_{(1,68)}=20.4, p<$ 0.0001 ; treatment $\times$ withdrawal, $F_{(1,68)}=0$, NS), perirenal (treatment, $F_{(1,68)}=15.8, p<0.001$; withdrawal, $F_{(1,68)}=22.7$, $p<0.0001$; treatment $\times$ withdrawal, $\left.F_{(1,68)}=0, \mathrm{NS}\right)$, mesenteric (treatment, $F_{(1,68)}=0.1, p<0.01$; withdrawal, $F_{(1,68)}=14.9, p<$ 0.001 ; treatment $\times$ withdrawal, $\left.F_{(1,68)}=3.0, p=0.09\right)$, and subcutaneous (treatment, $F_{(1,68)}=11.4, p<0.01$; withdrawal, $F_{(1,68)}=18.5, p<0.0001$; treatment $\times$ withdrawal, $F_{(1,68)}=0$, NS) fat depot weights (Table 2). Twelve hours after the final morphine injection, relative weights of perirenal $(p<0.001)$, mesenteric $(p<0.01)$, and subcutaneous $(p<0.001)$ fat depots were significantly reduced in morphine-treated rats. However, the relative weight of the epidydimal fat depot was not altered 12 $\mathrm{hr}$ after termination of morphine treatment. Eight days after the final morphine injection, relative weights of all of the depots, except the perirenal depot $(p<0.05)$, had recovered in morphine-treated rats.

\section{Leptin and insulin concentrations}

Morphine dependence and withdrawal transiently decreased plasma leptin (treatment, $F_{(1,68)}=35.0, p<0.0001$; withdrawal, $F_{(1,68)}=42.1, p<0.0001$; treatment $\times$ withdrawal, $F_{(1,68)}=11.8$, $p<0.001)$ and insulin (treatment, $F_{(1,68)}=40.8, p<0.0001$; withdrawal, $F_{(1,68)}=36.1, p<0.0001$; treatment $\times$ withdrawal, $F_{(1,68)}=7.7, p<0.01$ ) concentrations (Fig. $2 A, B$ ). Plasma leptin 
Tail Nick
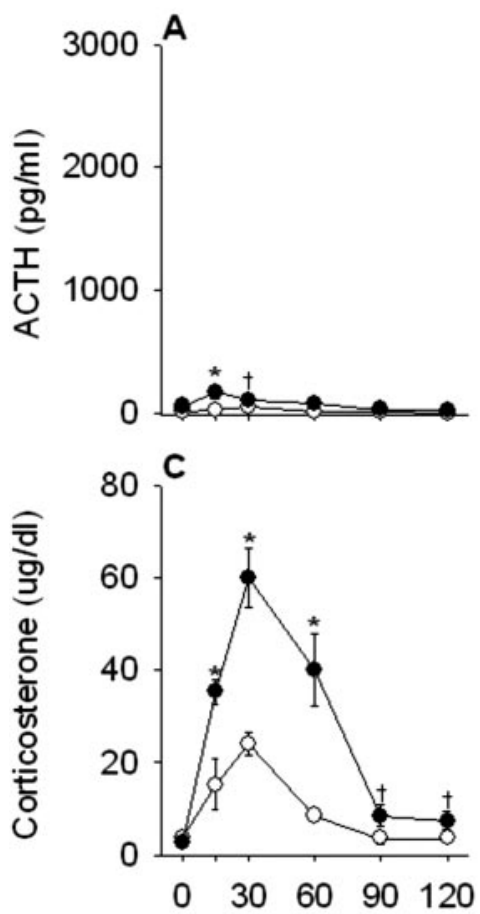

Time (min)
Tail Nick+Restraint

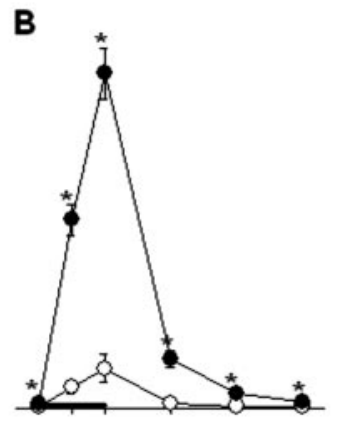

D

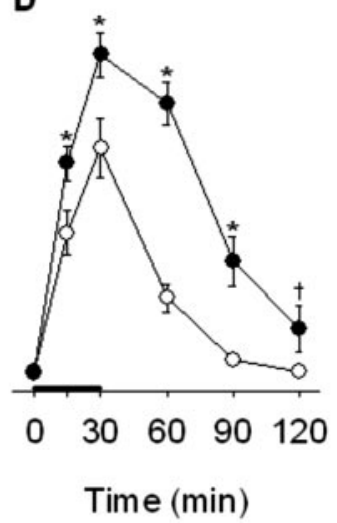

Time $(\min )$

\section{$\multimap 12 \mathrm{~h}$ Vehicle \\ $\rightarrow$ 12h Morphine}

Figure 4. The ACTH and corticosterone responses to the acute, novel stress of tail nick +30 min restraint were significantly facilitated in morphine-treated rats $12 \mathrm{hr}$ after their final morphine injection. Rats received injections twice daily of saline or morphine for 8 consecutive days. On day 9, the $A C T H$ and corticosterone responses to tail nick alone ( $A$ and $C$, respectively) or tail nick +30 min restraint ( $B$ and $D$, respectively) were examined. Restraint stress was initiated immediately after the initial tail nick at 0 min and lasted $30 \mathrm{~min}$, as indicated by the thick black bar. Blood was collected under basal conditions ( $0 \mathrm{~min}$ ), as well as 15, 30,60, 90, and $120 \mathrm{~min}$ after the initial tail nick. The results are expressed as means $\pm \operatorname{SEM}\left(n=6\right.$ rats per group). ${ }^{*} p<$ 0.05 indicates significant effect of morphine versus saline treatment. $+0.1<p<0.05$ indicates a trend toward a significant effect of morphine versus saline treatment.

$(p<0.001)$ and insulin $(p<0.001)$ concentrations were significantly reduced $12 \mathrm{hr}$ after the final morphine injection but had recovered $8 \mathrm{~d}$ later.

\section{Gonadal activity}

Testosterone concentrations

Plasma testosterone concentrations serve as an index of the effects of stressors on the hypothalamo-pituitary-gonadal axis; activity in this system is inhibited by many, but not all, of the chronic stressors (Dallman et al., 2002). Morphine dependence and withdrawal dramatically and transiently decreased plasma testosterone concentrations (treatment, $F_{(1,68)}=16.2, p<$ 0.0001 ; withdrawal, $F_{(1,68)}=16.2, p<0.0001$; treatment $\times$ withdrawal, $\left.F_{(1,68)}=20.1, p<0.0001\right)$. Plasma testosterone concentrations were significantly reduced $12 \mathrm{hr}$ after the final morphine injection (vehicle, $1.45 \pm 0.14 \mathrm{ng} / \mathrm{ml}$ vs morphine, $0.23 \pm 0.06$ $\mathrm{ng} / \mathrm{ml} ; p<0.0001$ ) and $8 \mathrm{~d}$ later had recovered to values observed in vehicle-treated rats (vehicle, $1.39 \pm 0.18 \mathrm{ng} / \mathrm{ml}$ vs morphine, $1.46 \pm 0.17 \mathrm{ng} / \mathrm{ml}$; NS).

Tail Nick
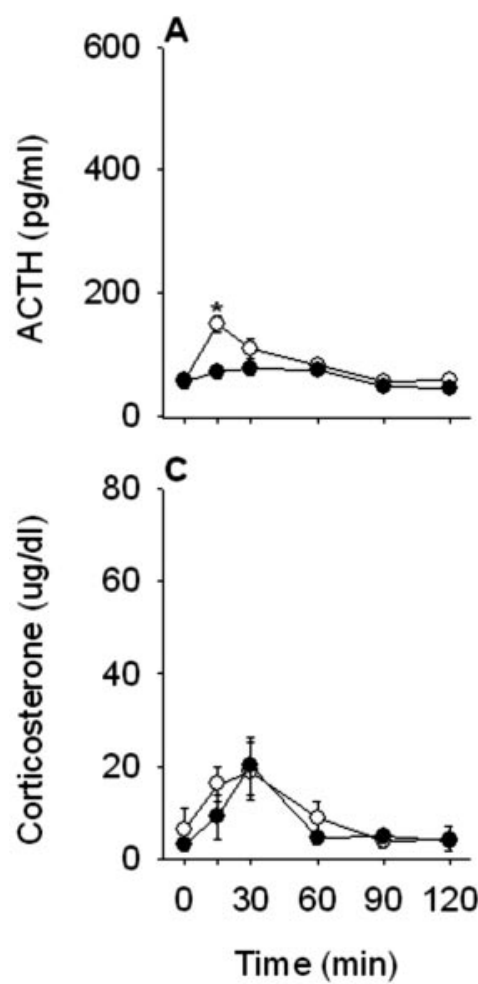

Tail Nick+Restraint

B

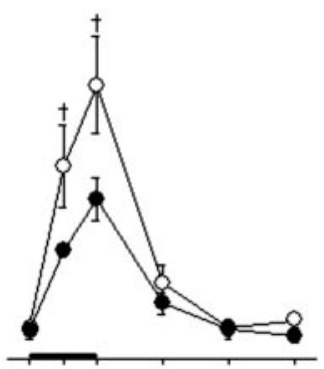

D

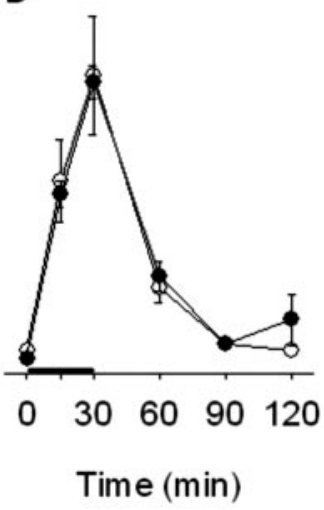

\section{- 0 d Vehicle \\ $\rightarrow$ 8d Morphine}

Figure 5. The ACTH response to the acute, novel stress of tail nick +30 min restraint was significantly reduced in morphine-treated rats $8 \mathrm{~d}$ after their final morphine injection. However, the corticosterone responses to the acute, novel stress of tail nick +30 min restraint were similar between morphine- and saline-treated rats $8 \mathrm{~d}$ after termination of morphine treatment. Rats received injections twice daily of saline or morphine for 8 consecutive days, followed by 8 additional days of saline injections in both treatment groups. On day 16, the ACTH and corticosterone responses to tail nick alone ( $A$ and $C$, respectively) or tail nick +30 min restraint ( $B$ and $D$, respectively) were examined. Restraint stress was initiated immediately after the initial tail nick at $0 \mathrm{~min}$ and lasted $30 \mathrm{~min}$, as indicated by the thick black bar. Blood was collected under basal conditions ( 0 min), as well as $15,30,60,90$, and 120 min after the initial tail nick. The results are expressed as means \pm SEM ( $n=6$ rats per group). ${ }^{*} p<0.05$ indicates significant effect of morphine versus saline treatment. $+0.1<p<0.05$ indicates a trend toward a significant effect of morphine versus saline treatment.

Pituitary-adrenal activity

Adrenal and thymus weights

Adrenal weight serves as an integrated measure of ACTH secretion over time (Jacobson et al., 1989). Morphine dependence and withdrawal significantly increased relative adrenal weight (treatment, $F_{(1,68)}=46.1, p<0.0001$; withdrawal, $F_{(1,68)}=16.2, p<$ 0.0001 ; treatment $\times$ withdrawal, $F_{(1,68)}=0.3$, NS) (Fig. $3 A$ ). Twelve hours after the final morphine injection, relative adrenal weights were significantly elevated in morphine-treated rats $(p<$ 0.001 ), suggesting a history of elevated ACTH secretion. Furthermore, $8 \mathrm{~d}$ after termination of morphine treatment, relative adrenal weights remained significantly elevated ( $p<0.001)$ compared with vehicle-treated controls.

Thymus weight serves as an integrated measure of inhibitory glucocorticoid action (Akana et al., 1985). Morphine withdrawal also significantly affected relative thymus weight (treatment, $F_{(1,68)}=14.4, p<0.001$; withdrawal, $F_{(1,68)}=117.0, p<0.0001$; 

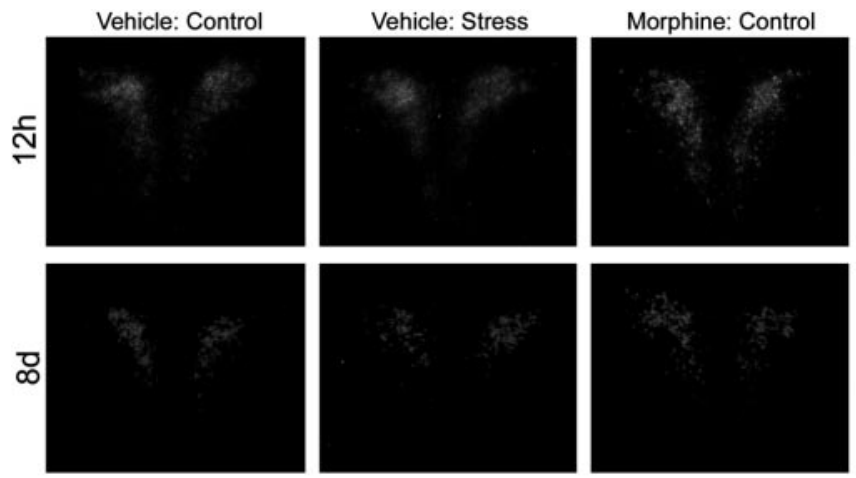

12h Withdrawal

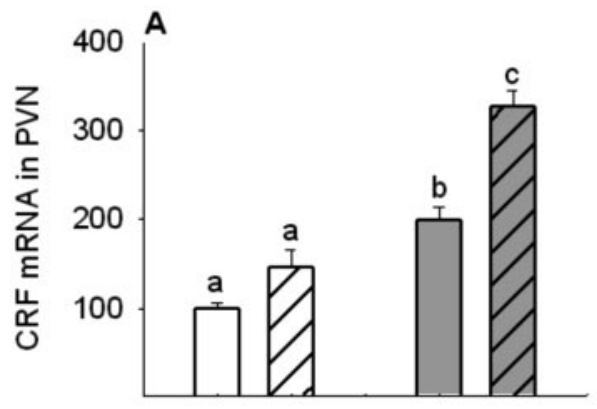

Vehicle: Control

Vehicle: Stress 8d Withdrawal

B

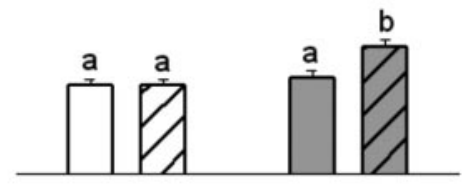

Morphine: Control

Morphine: Stress

Figure 6. Twelve hours after the final morphine injection, CRF mRNA expression in the PVN was increased, and CRF mRNA response to the novel, acute stress of 30 min restraint was facilitated ( $A$, top). Eight days after final morphine injection, PVN CRF mRNA expression had recovered, but rats maintained a facilitated CRF mRNA response to the novel stress of restraint $(B$, bottom). The top two rows show dark-field photomicrographs of CRF mRNA responses in the PVN at $12 \mathrm{hr}$ (top) and $8 \mathrm{~d}$ (bottom) after the final morphine injection. Sections were selected to represent the mean responses shown in $A$ and $B$. $A, B$, CRF mRNA data are expressed as a percentage of vehicle control. The results are expressed as means \pm SEM ( $n=4$ rats per group). Different letters indicate a significant $(p<0.05)$ difference.

treatment $\times$ withdrawal, $\left.F_{(1,68)}=42.1, p<0.0001\right)$ (Fig. $3 B$ ). Twelve hours after the last morphine injection, relative thymus weights were similar between vehicle- and morphine-treated rats (Fig. 3B). However, $8 \mathrm{~d}$ after termination of morphine treatment, relative thymus weights were significantly reduced in morphinetreated rats compared with vehicle-treated controls $(p<0.001)$.

ACTH and corticosterone responses to a novel stressor $12 \mathrm{hr}$ after the last morphine injection

Basal plasma ACTH was similar between vehicle- and morphinetreated rats $12 \mathrm{hr}$ after the last morphine injection (Fig. 4A,B). Acute exposure to restraint produced significant increases in plasma ACTH concentrations in both vehicle-treated (treatment, $F_{(1,10)}=4.8, p=0.05$; time, $F_{(5,50)}=9.3, p<0.0001$; treatment $\times$ time, $\left.F_{(5,50)}=5.3, p<0.001\right)$ and $12 \mathrm{hr}$ morphine-withdrawn (treatment, $F_{(1,10)}=p<0.001$; time, $F_{(5,50)}=110.4, p<0.0001$; treatment $\times$ time, $\left.F_{(5,50)}=96.5, p<0.0001\right)$ rats. Furthermore, the ACTH responses to both tail nick alone (treatment, $F_{(1,10)}=$ 6.9, $p<0.05$; time, $F_{(5,50)}=5.3, p<0.001$; treatment $\times$ time, $F_{(5,50)}=2.7, p<0.05$ ) and tail nick + restraint stress (treatment, $F_{(1,10)}=181.2, p<0.0001$; time, $F_{(5,50)}=114.7, p<0.0001$; treatment $\times$ time, $\left.F_{(5,50)}=72.7, p<0.0001\right)$ were significantly greater in morphine-treated rats compared with vehicle-treated rats $12 \mathrm{hr}$ after the last morphine injection.
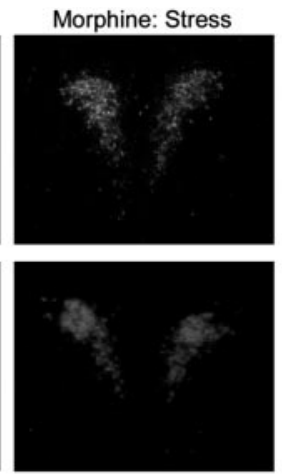

Initial corticosterone concentrations were also similar between vehicle- and morphine-treated rats $12 \mathrm{hr}$ after the final morphine injection (Fig. 4C,D). Acute restraint resulted in a significant increase in plasma corticosterone concentration in vehicle-treated (treatment, $F_{(1,10)}=14.7$, $p<0.01$; time, $F_{(5,50)}=46.2, p<0.0001$; treatment $\times$ time, $F_{(5,50)}=8.2, p<$ 0.0001 ) and morphine-treated (treatment, $F_{(1,10)}=8.2, p<0.05$; time, $F_{(5,50)}=90.1, p<0.0001$; treatment $\times$ time, $\left.F_{(5,50)}=2.5, p<0.05\right)$ rats. However, morphine-treated rats demonstrated a greater corticosterone response to both tail nick alone (treatment, $F_{(1,10)}=35.6$, $p<0.001$; time, $F_{(5,50)}=40.6, p<0.0001$; treatment $\times$ time, $F_{(5,50)}=10.5, p<$ 0.0001 ) and tail nick + restraint (treatment, $F_{(1,10)}=24.5, p<0.001$; time, $F_{(5,50)}=96.0, p<0.0001$; treatment $\times$ time, $\left.F_{(5,50)}=9.5, p<0.0001\right) 12 \mathrm{hr}$ after the final morphine injection. As anticipated (Houshyar et al., 2001a,b, 2003a), rats had facilitated ACTH and corticosterone responses at the end of this chronic stressor.

\section{ACTH and corticosterone responses to a novel stressor $8 d$ after the last \\ morphine injection}

Basal plasma ACTH was similar between vehicle- and morphine-treated rats $8 \mathrm{~d}$ after the last morphine injection (Fig. $5 A, B)$. Acute exposure to restraint produced significant increases in plasma ACTH in vehicle (treatment, $F_{(1,10)}=7.8$, $p<0.05$; time, $F_{(5,50)}=27.5, p<0.0001$; treatment $\times$ time, $F_{(5,50)}=13.2, p<$ $0.0001)$ and $8 \mathrm{~d}$ morphine-withdrawn (treatment, $F_{(1,10)}=9.7, p<0.05$; time, $F_{(5,50)}=35.0, p<0.0001$; treatment $\times$ time, $F_{(5,50)}=21.4, p<$ $0.001)$ rats. Furthermore, the ACTH responses to both tail nick alone (treatment, $F_{(1,10)}=7.1, p<0.05$; time, $F_{(5,50)}=18.6, p<$ 0.001 ; treatment $\times$ time, $\left.F_{(5,50)}=6.6, p<0.0001\right)$ and tail nick + restraint stress (treatment, $F_{(1,10)}=4.0, p=0.07$; time, $F_{(5,50)}=$ $41.1, p<0.001$; treatment $\times$ time, $\left.F_{(5,50)}=3.7, p<0.01\right)$ were significantly reduced in morphine-treated rats compared with vehicle-treated rats $8 \mathrm{~d}$ after the last morphine injection.

Basal corticosterone concentrations were similar in vehicleand morphine-treated rats undergoing $8 \mathrm{~d}$ of morphine withdrawal (Fig. 5C,D). Acute exposure to restraint produced significant increases in plasma corticosterone concentrations in both vehicle-treated (treatment, $F_{(1,10)}=6.5, p<0.05$; time, $F_{(5,50)}=$ $21.0, p<0.0001$; treatment $\times$ time, $\left.F_{(5,50)}=7.7, p<0.0001\right)$ and $8 \mathrm{~d}$ morphine-withdrawn (treatment, $F_{(1,10)}=28.6, p<0.0001$; time, $F_{(5,50)}=50.5, p<0.0001$; treatment $\times$ time, $F_{(5,50)}=17.5$, $p<0.0001)$ rats. Thus, $8 \mathrm{~d}$ of escalating intermittent morphine treatment is sufficient to provide robust effects on the HPA axis $8 \mathrm{~d}$ later. There were no significant differences in the corticosterone responses to tail nick + restraint between vehicle- and morphine-treated rats, showing that the hyper-responsivity of the HPA axis observed $12 \mathrm{hr}$ after the final morphine injection 


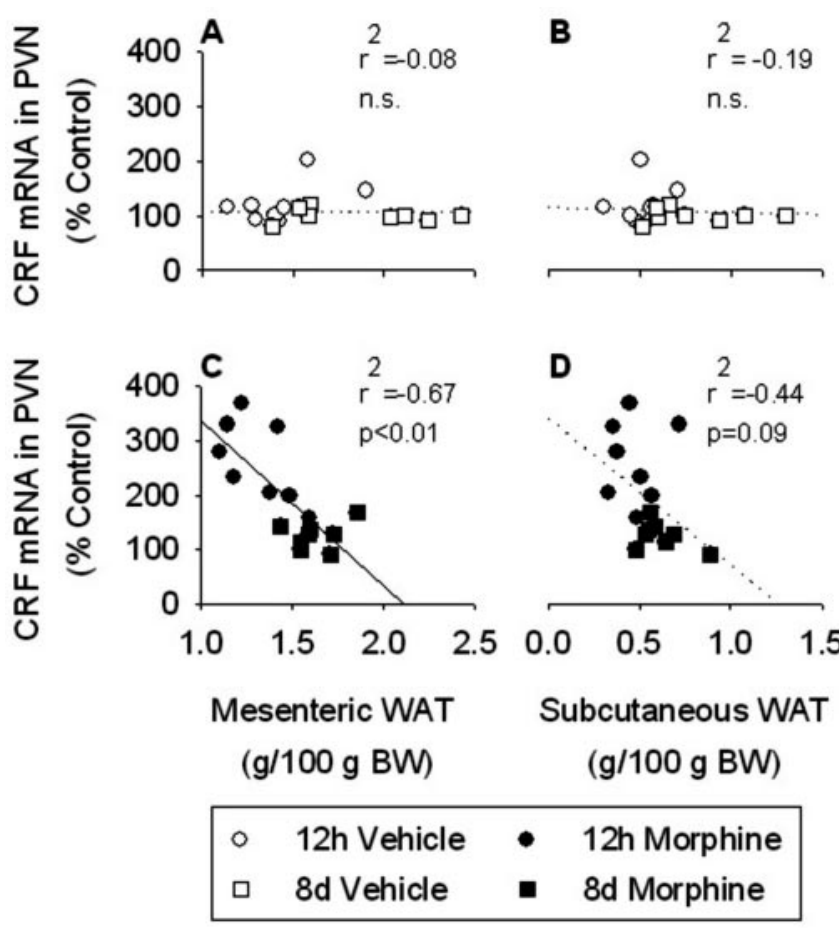

Figure 7. There was no correlation between CRF mRNA expression in the PVN and either mesenteric or subcutaneous WAT weight in vehicle-treated rats ( $A$ and $B$, respectively). In contrast, there was a strong negative correlation between CRF mRNA expression in the PVN and mesenteric WAT in morphine-treated rats ( $C$. In addition, there was a nonsignificant trend toward a negative correlation between CRF mRNA expression in the PVN and subcutaneous WAT in morphine-treated rats (D). CRF mRNA data are expressed as a percentage of vehicle control. Mesenteric and subcutaneous WAT data are expressed relative to body weight. The results are expressed as means \pm SEM ( $n=16$ rats per group). The solid line indicates a significant $(p<0.05)$ correlation.

did not persist for $8 \mathrm{~d}$ (tail nick, treatment, $F_{(1,10)}=0.4$, NS; time, $F_{(5,50)}=8.0, p<0.0001$; treatment $\times$ time, $F_{(5,50)}=0.6$, NS; tail nick + restraint, treatment, $F_{(1,10)}=0$, NS; time, $F_{(5,50)}=52.2$, $p<0.0001$; treatment $\times$ time, $F_{(5,50)}=0.3$, NS). The lack of an inhibited corticosterone response $8 \mathrm{~d}$ after withdrawal from morphine, despite a robustly inhibited ACTH response, may have resulted from enlarged adrenals that were more than usually responsive to low amounts of ACTH.

CRF $m R N A$ expression in the PVN $12 \mathrm{hr}$ and $8 \mathrm{~d}$ after the last morphine injection: correlations with white fat depots

CRF mRNA levels in the PVN were significantly altered $12 \mathrm{hr}$ after the final morphine injection (treatment, $F_{(1,12)}=77.3, p<$ 0.0001 ; stress, $F_{(1,12)}=30.0, p<0.0001$; treatment $\times$ stress, $F_{(1,12)}=6.7, p<0.05$ ) (Fig. $6 \mathrm{~A}$, top panels). CRF mRNA in the PVN in $12 \mathrm{hr}$ morphine-withdrawn rats was significantly increased compared with vehicle-treated rats $(p<0.01)$. Furthermore, $12 \mathrm{hr}$ after the final morphine injection, responsivity of CRF mRNA in the PVN to restraint stress was significantly increased in morphine-treated rats compared with the vehicletreated controls $(p<0.001)$. CRF mRNA levels in the PVN were also different $8 \mathrm{~d}$ after the final morphine injection (treatment, $F_{(1,12)}=11.8, p<0.01$; stress, $F_{(1,12)}=5.9, p<0.05$; treatment $\times$ stress, $F_{(1,12)}=5.2, p<0.05$ ) (Fig. $6 B$, bottom panels). Eight days after the final morphine injection, CRF mRNA in the PVN in morphine-treated rats had recovered to levels observed in vehicle-treated rats. However, facilitated responsivity of CRF mRNA in the PVN to restraint stress remained $(p<0.05)$.

Based on our previous studies, we were interested in the rela- tionship between WAT weights and CRF mRNA expression in the PVN (Dallman et al., 2003b). There were no significant correlations between CRF mRNA levels in the PVN and any of the white fat depots examined in vehicle-treated rats (epidydimal, $r^{2}=-0.14$, NS; mesenteric, $r^{2}=-0.09$, NS; perirenal, $r^{2}=$ -0.14 , NS; subcutaneous, $r^{2}=-0.19$, NS) (Fig. $7 A, B$ ). In contrast, we found a strong negative correlation $\left(r^{2}=-0.67 ; p<\right.$ 0.01 ) between CRF mRNA expression in the PVN and mesenteric WAT weight in morphine-treated rats (Fig. 7C). There were no significant correlations between CRF mRNA in the PVN and epidydimal $\left(r^{2}=-0.23\right.$; NS) or perirenal $\left(r^{2}=-0.36\right.$; NS) WAT, although there was a trend toward a correlation between CRF mRNA and subcutaneous WAT $\left(r^{2}=-0.44 ; 0.1<p<\right.$ 0.05 ) (Fig. 7D) in morphine-treated rats. The results suggest that, when the central stress response network is engaged, a signal from abdominal fat stores modulates activity in this network, as reported previously (Laugero, 2001; Dallman et al., 2003b).

CRF mRNA expression in the amygdala, Barrington's nucleus, and BNST $12 \mathrm{hr}$ and $8 \mathrm{~d}$ after the last morphine injection

Twelve hours after the final morphine injection, CRF mRNA expression in the CeA was significantly reduced in morphinetreated rats compared with vehicle-treated rats $\left(F_{(1,14)}=5.9 ; p<\right.$ 0.04 ) (Table 3 ). In contrast, $8 \mathrm{~d}$ after the final morphine injection, CRF mRNA expression in the CeA of morphine-treated rats tended to be higher than in the vehicle-treated controls $\left(F_{(1,14)}=\right.$ $3.3 ; p=0.09)$. CRF mRNA expression in Barrington's nucleus was significantly elevated $12 \mathrm{hr}\left(F_{(1,14)}=4.7 ; p<0.05\right)$ after the final morphine injection and remained elevated $8 \mathrm{~d}$ after the final morphine injection $\left(F_{(1,14)}=6.3 ; p<0.05\right)$ compared with vehicle-treated controls (Table 3 ). Twelve hours after the final morphine injection, CRF mRNA expression in both the oval and fusiform nuclei of the BNST were significantly elevated in morphine-treated rats compared with vehicle-treated controls $\left(\right.$ oval, $F_{(1,14)}=11.6, p<0.01$; fusiform, $\left.F_{(1,14)}=8.5 ; p<0.05\right)$ (Table 3). However, $8 \mathrm{~d}$ later, CRF mRNA levels in both of the BNST nuclei had recovered and were similar to those observed in vehicle-treated rats.

AVP mRNA expression in the PVN $12 \mathrm{hr}$ and $8 \mathrm{~d}$ after the last morphine injection

AVP mRNA expression in the magnocellular cells of the PVN was unaltered both $12 \mathrm{hr}$ and $8 \mathrm{~d}$ after the final morphine injection (Fig. 8A). AVP mRNA levels in the parvocellular cells of the PVN were significantly elevated in morphine-treated rats $12 \mathrm{hr}$ after the final morphine injection compared with vehicle-treated rats $\left(F_{(1,14)}=4.6 ; p=0.05\right)$ (Fig. $8 \mathrm{~B}$, top panel). However, $8 \mathrm{~d}$ later, parvocellular PVN AVP mRNA expression in morphine-treated rats had recovered and was similar to control rats (Fig. $8 \mathrm{~B}$, bottom panel).

NPY and POMC mRNA expression in the arcuate nucleus of the hypothalamus $12 \mathrm{hr}$ and $8 \mathrm{~d}$ after the last morphine injection In the anterior arcuate, mRNA expression of the orexigenic NPY was significantly reduced in morphine-treated rats $12 \mathrm{hr}$ after the final morphine injection $\left(F_{(1,14)}=5.6 ; p<0.05\right)$ (Table 4). In contrast, $8 \mathrm{~d}$ after the final morphine injection, NPY mRNA expression in the anterior arcuate was significantly increased in morphine-treated rats compared with the vehicle-treated controls $\left(F_{(1,14)}=7.8 ; p<0.05\right)$. NPY mRNA expression in the medial and posterior regions of the arcuate nucleus of the hypothalamus was unaltered either $12 \mathrm{hr}$ or $8 \mathrm{~d}$ after the final morphine injection in morphine-treated animals compared with vehicle-treated controls. These findings are consistent with pre- 
Table 3. Effects of administration twice daily of escalating doses of morphine for 8 consecutive days during early (12 $\mathrm{hr}$ ) and late ( $8 \mathrm{~d}$ ) withdrawal on CRF mRNA expression in various nuclei in the brain

\begin{tabular}{|c|c|c|c|c|}
\hline & \multicolumn{2}{|c|}{$12 \mathrm{hr}$ withdrawal } & \multicolumn{2}{|c|}{$8 \mathrm{~d}$ withdrawal } \\
\hline & Vehicle & Morphine & Vehicle & Morphine \\
\hline \multicolumn{5}{|l|}{ CRF } \\
\hline Amygdala & $97 \pm 7$ & $72 \pm 8^{* *}$ & $91 \pm 11$ & $142 \pm 25^{*}$ \\
\hline Barrington's nucleus & $99 \pm 5$ & $119 \pm 8^{* *}$ & $115 \pm 12$ & $186 \pm 25^{* *}$ \\
\hline BNST oval & $107 \pm 12$ & $169 \pm 13^{* * *}$ & $97 \pm 6$ & $93 \pm 7$ \\
\hline BNST fusiform & $91 \pm 8$ & $144 \pm 16^{* *}$ & $106 \pm 7$ & $99 \pm 7$ \\
\hline
\end{tabular}

Data are expressed as a percentage of vehicle control. Values represent the mean \pm SEM of eight rats per group. Vehicle versus morphine treated: ${ }^{*} 0.1<p<$ $0.05 ;{ }^{* *} p<0.05 ;{ }^{* * *} p<0.01$
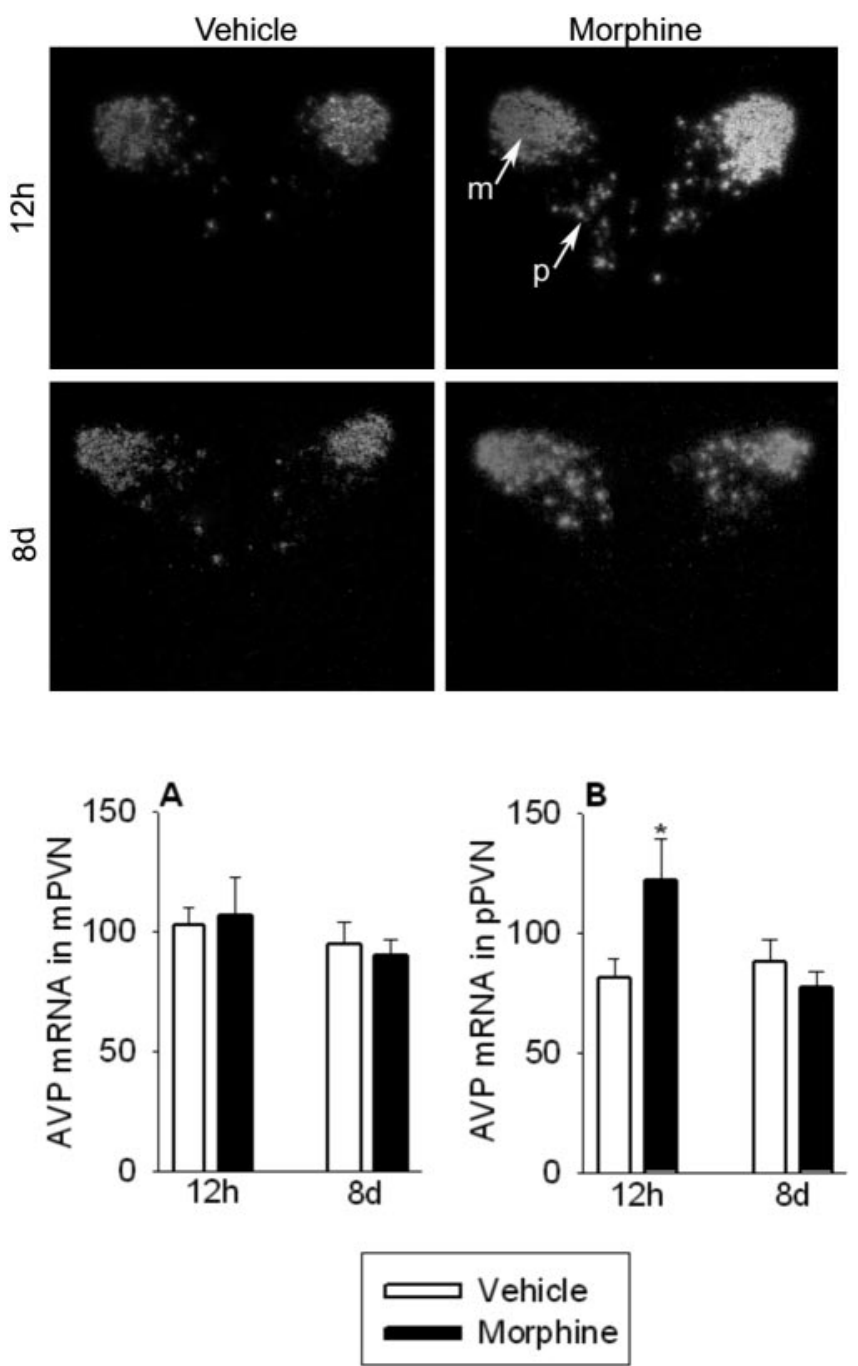

Figure 8. Twelve hours after the final morphine injection, AVP mRNA expression in the parvocellular cells of the PVN (pPVN) was significantly elevated ( $B$; top) but had recovered $8 \mathrm{~d}$ later ( $B$; bottom). AVP mRNA expression in the magnocellular cells of the PVN (mPVN) was unaltered $12 \mathrm{hr}$ ( $A$; top) and $8 \mathrm{~d}$ ( $A$; bottom) after the final morphine injection. The two panels show darkfield photomicrographs of AVP mRNA responses in the PVN at $12 \mathrm{hr}$ (top) and $8 \mathrm{~d}$ (bottom) after the final morphine injection. Sections were selected to represent the mean responses shown in $A$ and $B . A, B$, AVP mRNA data are expressed as a percentage of vehicle control. The results are expressed as means \pm SEM ( $n=8$ rats per group). Different letters indicate a significant $(p<0.05)$ difference.

vious observations in our laboratory that two very different manipulations, namely lesioning the afferents from the ARC to the PVN (Bell et al., 2000) and exposing rats to chronic cold stress plus high testosterone levels (F. Gomez, personal communica- tion), selectively alter NPY mRNA expression in the anterior, but not the medial or posterior, portions of the arcuate nucleus of the hypothalamus. The anorexogenic POMC mRNA expression levels in the anterior, medial, and posterior regions of the arcuate nucleus of the hypothalamus were not different either $12 \mathrm{hr}$ or $8 \mathrm{~d}$ after the final morphine injection in morphinetreated rats compared with vehicle-treated controls (Table 4). Thus, in the anterior arcuate, orexigenic NPY mRNA levels were decreased when food intake was low, $12 \mathrm{hr}$ after morphine, and were increased $8 \mathrm{~d}$ after the last injection of morphine when food intake was normal but energy efficiency was high.

\section{Discussion}

The $8 \mathrm{~d}$ morphine paradigm is sufficient to both activate the chronic stress response network of the brain and leave sequelae of the effects of the chronic stressor that persist for at least $8 \mathrm{~d}$ after the last injection. The stress of repeated withdrawal associated with intermittent morphine treatment $(12 \mathrm{hr})$ reliably altered brain neuropeptide expression and neuroendocrine and metabolic variables. The newly described delayed effects $(8 \mathrm{~d})$ after morphine withdrawal on brain peptide expression were robust and revealing. We suspect that some of the differences between $4 \mathrm{~d}$ (Houshyar et al., 2003a) and $8 \mathrm{~d}$ morphine treatments result from the more marked metabolic and endocrine effects of the longer treatment (Table 5). There were persistent changes in several CRF-containing cell groups in the brain and robustly altered HPA responses of morphine-treated rats not only $12 \mathrm{hr}$, but also $8 \mathrm{~d}$, after the end of treatment, consistent with changes in energy balance. The delayed changes may also reflect what happens in people with posttraumatic stress disorder (PTSD) and may represent interactions between physical recovery from, but sustained brain effects of, high-intensity stressors. Repeated partial withdrawal associated with intermittent morphine treatment appears to be required for induction of this chronic stress state.

\section{Energy balance}

Eight days of morphine treatment, like the $4 \mathrm{~d}$ paradigm, reduced food intake, body weight, and caloric efficiency. However, only $8 \mathrm{~d}$, but not $4 \mathrm{~d}$, of morphine reduced fat depot weights. Furthermore, the marked physical withdrawal that occurred between 24 and $48 \mathrm{hr}$ after $8 \mathrm{~d}$ was much more pronounced than after $4 \mathrm{~d}$ of morphine; caloric efficiency was twice as reduced. During the last days, caloric efficiency reached control after $4 \mathrm{~d}$ of morphine, but, after $8 \mathrm{~d}$ of morphine, caloric efficiency was above control for the last $4 \mathrm{~d}$. This suggests strongly that the $8 \mathrm{~d}$ treatment constitutes a greater metabolic challenge and initiates greater compensation during the $8 \mathrm{~d}$ of recovery.

NPY mRNA levels were reduced when rats ate less at $12 \mathrm{hr}$ and were elevated when they ate normally $8 \mathrm{~d}$ after the last morphine injection. NPY may have affected caloric efficiency via inhibition of sympathetic outflow (Bray, 1991; Egawa et al., 1991). Considering all of the samples, CRF mRNA in the PVN correlated negatively with NPY mRNA in the ARC of morphine-treated rats $\left(r^{2}=-0.64 ; p<0.01\right)$, supporting the proposed opposing roles of these neuropeptides in the regulation of food intake (Richard et al., 2002; Williams et al., 2004). NPY levels are reduced in the hypothalamus of morphine-tolerant rats (Pages et al., 1991), and intracerebroventricular NPY attenuates withdrawal-induced behavioral signs and neuronal activation (Woldbye et al., 1998; 
Clausen et al., 2001), suggesting that NPY may play a role in morphine withdrawal.

Expression of POMC was unchanged throughout the experiment, in agreement with a report stating that repeated morphine injections and naloxoneprecipitated withdrawal did not change POMC mRNA expression in the ARC (Lightman and Young, 1988). In contrast, other studies have shown that POMC expression is decreased in morphinedependent and -withdrawing rats (Mocchetti et al., 1989; Bronstein et al., 1990; Wardlaw et al., 1996). However, those studies were performed in animals with steady-state morphine, and intermittent morphine produces markedly different effects than constant morphine.

\section{HPA activity}

ACTH and corticosterone responses to acute restraint were facilitated $12 \mathrm{hr}$ after the last morphine injection and reduced $8 \mathrm{~d}$ thereafter. With $8 \mathrm{~d}$ of morphine treatment, the effect on both ACTH and corticosterone responsivity grows compared with $4 \mathrm{~d}$ of treatment, both $12 \mathrm{hr}$ and $8 \mathrm{~d}$ after the final morphine injection. Continued growth beyond an $8 \mathrm{~d}$ treatment is apparent when results from $16 \mathrm{~d}$ treatments are examined (Houshyar et al., 2001a,b). There, the facilitation of acute responses to novel restraint is still more robust, and the subsequent inhibition after $8 \mathrm{~d}$ of withdrawal persists for $16 \mathrm{~d}$. Thus, it appears that the duration of the morphine paradigm is as critical to the magnitude of changes in HPA responses as it is to energy balance.

At $12 \mathrm{hr}$, intermittent morphine treatment had similar stimulatory effects on CRF expression in the PVN and Barrington's nucleus in both the 4 and $8 \mathrm{~d}$ paradigms, suggesting that autonomic control (Pinelli et al., 1998; Cano et al., 2000) and neuroendocrine cell groups that are stressor sensitive (Sawchenko et al., 2000) are stimulated early and persistently after the onset of a chronic stressor. At $12 \mathrm{hr}$, the hypothalamic CRF response to acute restraint was increased with both 4 and $8 \mathrm{~d}$ morphine treatments. Enhanced CRF expression is consistent with facilitated ACTH responses at $12 \mathrm{hr}$. However, facilitation of CRF after restraint also occurs $8 \mathrm{~d}$ after the final morphine injection, when the ACTH response is reduced. Elevated CSF concentrations of CRF with low or normal plasma cortisol concentrations also occur in nonhuman primates exposed to early-life stressors (Coplan et al., 1996) and in humans with PTSD (Kasckow et al., 2001). Eight days after the last morphine injection, CRF mRNA remained elevated in Barrington's nucleus, suggesting persistent stimulation of CRF-expressing neurons in this autonomic control site.

At $12 \mathrm{hr}$, CRF mRNA in BNST was inhibited after $4 \mathrm{~d}$ but increased after $8 \mathrm{~d}$ of morphine. In the amygdala, $4 \mathrm{~d}$ of morphine did not affect CRF expression; after $8 \mathrm{~d}$ of morphine, CRF mRNA in amygdala was inhibited acutely $(12 \mathrm{hr}$ ) but elevated chronically (8 d). Similarly, it was reported recently that CRF expression in the CeA increases with time, after withdrawal from intermittent morphine treatment (Maj et al., 2003). Stressor inputs affect activity in the BNST and amygdala in an interactive manner, and CRF seems to play a large role in the chronic stress response network (Gray et al., 1993; Schulkin et al., 1994; Gray and Bingaman, 1996; Walker and Davis, 1997; Koob and Heinrichs, 1999; Erb et al., 2001; McNally and Akil, 2002). The changes in CRF mRNA in highly interconnected limbic structures with different durations of morphine treatment suggest that some consolidation of responses to the chronic stressor may have occurred, but additional experiments are required for precise interpretation.

At $12 \mathrm{hr}$, AVP mRNA in parvocellular PVN did not change after $4 \mathrm{~d}$ but increased in the $8 \mathrm{~d}$ paradigm; although colocalization was not performed, it is likely that at least some of the parvocellular AVP was coexpressed in CRF neurons after chronic stressors, as reported by others (de Goeij et al., 1992; Ma and Aguilera, 1999). The increased AVP between 4 and $8 \mathrm{~d}$ treatments could help to explain some of the growth in the magnitude of ACTH responses to novel restraint that occurred during this period (Rivier and Vale, 1983; Rivier et al., 1984). Increased AVP expression is consistent with the increasing role of this neuropeptide in regulating HPA activity during chronic stress (Makino et al., 1995; Ma and Aguilera, 1999; Ma et al., 1999).

There is a relationship between energy balance and HPA ac- 
tivity during periods of chronic stress (Dallman et al., 2004). Morphine-treated rats displayed a strong negative correlation between mesenteric WAT weight and CRF mRNA expression in the PVN. There was also a strong negative correlation between mesenteric WAT and CRF expression in the BNST (oval, $r^{2}=-0.73$, $p<0.01$; fusiform, $r^{2}=-0.72, p<0.01$ ). The opposite effects of 4 and $8 \mathrm{~d}$ morphine paradigms on CRF expression in the BNST may reflect the fact that only $8 \mathrm{~d}$ of morphine reduced mesenteric fat depot weights. These changes support a role for metabolic negative feedback during periods of chronic stress but require experiments designed to test the hypothesis more directly.

\section{Relevance to humans}

The rate of substance abuse, including opioid dependence, is prevalent among people with PTSD (Clark et al., 2001; Jacobsen et al., 2001; De Bellis, 2002). Our results suggest that opioid dependence and withdrawal may result in development of PTSD. PTSD is associated with increased CRF concentrations in CSF, normal or low cortisol levels, and supersuppression with dexamethasone (Jacobsen et al., 2001). Similarly, we observe a mismatch between central CRF expression and peripheral pituitaryadrenal secretions in $8 \mathrm{~d}$ rats. CRF mRNA expression in the PVN, Barrington's nucleus, and the amygdala is elevated $8 \mathrm{~d}$ after the final morphine injection, but rats display markedly reduced ACTH responses to a novel stressor. Also, rats undergoing $8 \mathrm{~d}$ of withdrawal are more sensitive to dexamethasone feedback (Houshyar et al., 2001b). We believe that precipitation of a PTSD-like state in morphine-treated rats is directly linked to the duration and intensity of morphine treatment and is coupled to the magnitude of the metabolic and endocrine responses that occur in response to opioid withdrawal. The mismatch between central and peripheral HPA activity may play a role during the chronic withdrawal, relapse-sensitive period and may be at least, in part, dependent on metabolic feedback.

\section{Summary}

Eight days of escalating morphine injections produce marked changes in the expression of neuropeptides involved in metabolism and HPA activity, some of which persist for at least $8 \mathrm{~d}$ after the last injection. With a longer duration of morphine treatment, the effect on energy balance and HPA activity both $12 \mathrm{hr}$ and $8 \mathrm{~d}$ after the final morphine injection grows. These results are likely a consequence of the stress associated with the twice-daily partial withdrawal that accompanies the injection regimen and the intense withdrawal response observed $24-48 \mathrm{hr}$ after the last morphine injection. Changes occurring in metabolism are linked with HPA activity and support an inhibitory metabolic feedback signal during periods of chronic stress. The newly described delayed effects of morphine dependence and withdrawal are similar to the HPA symptoms described in people with PTSD.

\section{References}

Akana SF, Cascio CS, Shinsako J, Dallman MF (1985) Corticosterone: narrow range required for normal body and thymus weight and ACTH. Am J Physiol 249:R527-R532.

Bell ME, Bhatnagar S, Akana SF, Choi SJ, Dallman MF (2000) Disruption of arcuate/paraventricular nucleus connections changes body energy balance and response to acute stress. J Neurosci 20:6707-6713.

Bray GA (1991) Reciprocal relation between the sympathetic nervous system and food intake. Brain Res Bull 27:517-520.

Bronstein DM, Przewlocki R, Akil H (1990) Effects of morphine treatment on pro-opiomelanocortin systems in rat brain. Brain Res 519:102-111.

Cano G, Card JP, Rinaman L, Sved A (2000) Connections of Barrington's nucleus to the sympathetic nervous system in rats. J Auton Nerv Syst 79:117-128.
Clark HW, Masson CL, Delucchi KL, Hall SM, Sees KL (2001) Violent traumatic events and drug abuse severity. J Subst Abuse Treat 20:121-127.

Clausen TR, Moller M, Woldbye DP (2001) Inhibitory effect of neuropeptide $\mathrm{Y}$ on morphine withdrawal is accompanied by reduced c-fos expression in specific brain regions. J Neurosci Res 64:410-417.

Coplan JD, Andrews MW, Rosenblum LA, Owens MJ, Friedman S, Gorman JM, Nemeroff CB (1996) Persistent elevations of cerebrospinal fluid concentrations of corticotropin-releasing factor in adult nonhuman primates exposed to early-life stressors: implications for the pathophysiology of mood and anxiety disorders. Proc Natl Acad Sci USA 93:1619-1623.

Dallman MF, Bhatnagar S (2001) Chronic stress and energy balance: role of the hypothalamo-pituitary-adrenal axis. In: Handbook of physiology, Sec 7, The endocrine system, Chap 10 (McEwen BS, ed), pp 179-210. New York: Oxford UP.

Dallman MF, Akana SF, Bhatnagar S, Bell ME, Choi S, Chu A, Horsley C, Levin N, Meijer O, Soriano LR, Strack AM, Viau V (1999) Starvation: early signals, sensors, and sequelae. Endocrinology 140:4015-4023.

Dallman MF, Viau V, Bhatnagar S, Gomez F, Laugero K, Bell ME (2002) Corticotropin-releasing factor (CRF), corticosteroids, stress and sugar: energy balance the brain and behavior. In: Hormones, brain and behavior, Vol 1, Chap 9 (Pfaff DW, ed), pp 571-631. San Diego: Academic.

Dallman MF, Akana SF, Laugero KD, Gomez F, Manalo S, Bell ME, Bhatnagar S (2003a) A spoonful of sugar: feedback signals of energy stores and corticosterone regulate responses to chronic stress. Physiol Behav 79:3-12.

Dallman MF, Pecoraro N, Akana SF, La Fleur SE, Gomez F, Houshyar H, Bell ME, Bhatnagar S, Laugero KD, Manalo S (2003b) Chronic stress and obesity: a new view of "comfort food." Proc Natl Acad Sci USA 100:11696-11701.

Dallman MF, La Fleur SE, Pecoraro NC, Gomez F, Houshyar H, Akana SF (2004) Glucocorticoids: food intake, abdominal obesity, and wealthy nations in 2004. Endocrinology 145:2633-2638.

De Bellis MD (2002) Developmental traumatology: a contributory mechanism for alcohol and substance use disorders. Psychoneuroendocrinology 27:155-170.

de Goeij DCE, Jezova D, Tilders FJH (1992) Repeated stress enhances vasopressin synthesis in corticotropin releasing factor neurons in the paraventricular nucleus. Brain Res 577:165-168.

Egawa M, Yoshimatsu H, Bray GA (1991) Neuropeptide Y suppresses sympathetic activity to interscapular brown adipose tissue in rats. Am J Physiol 260:R328-R334.

Erb S, Salmaso N, Rodaros D, Stewart J (2001) A role for the CRFcontaining pathway from central nucleus of the amygdala to bed nucleus of the stria terminalis in the stress-induced reinstatement of cocaine seeking in rats. Psychopharmacology 158:360-365.

Goeders NE (2002) Stress and cocaine addiction. J Pharmacol Exp Ther 301:785-789.

Gray TS, Bingaman EW (1996) The amygdala: corticotropin-releasing factor, steroids and stress. Crit Rev Neurobiol 10:155-168.

Gray TS, Piechowski RA, Yracheta JM, Rittenhouse PA, Bethea CL, Van de Kar LD (1993) Ibotenic acid lesions in the bed nucleus of the stria terminalis attenuate conditioned stress-induced increases in prolactin, ACTH and corticosterone. Neuroendocrinology 57:517-524.

Houshyar H, Cooper ZD, Woods JH (2001a) Paradoxical effects of chronic morphine treatment on the temperature and pituitary-adrenal responses to acute restraint stress: a chronic stress paradigm. J Neuroendocrinol $13: 862-874$.

Houshyar H, Galigniana MD, Pratt WB, Woods JH (2001b) Differential responsivity of the HPA axis to glucocorticoid negative feedback and corticotropin-releasing hormone in rats undergoing acute and chronic morphine withdrawal: possible mechanisms involved in facilitated and attenuated stress responses. J Neuroendocrinol 13:875-886.

Houshyar H, Gomez F, Manalo S, Bhargava A, Dallman MF (2003a) Intermittent morphine administration induces dependence and is a chronic stress in rats. Neuropsychopharmacology 28:1960-1972.

Houshyar H, Manalo S, Dallman MF (2003b) Intermittent morphine treatment produces long lasting alterations in metabolic and hypothalamicpituitary-adrenal responses to a novel stressor. Soc Neurosci Abstr 29:342.7.

Jacobsen LK, Southwick SM, Kosten TR (2001) Substance use disorders in patients with posttraumatic stress disorder: a review of the literature. Am J Psychiatry 158:1184-1190. 
Jacobson L, Akana SF, Cascio CS, Scribner K, Shinsako J, Dallman MF (1989) The adrenocortical system responds slowly to the removal of corticosterone in the absence of stress. Endocrinology 124:2144-2152.

Kasckow JW, Baker D, Geracioti Jr TD (2001) Corticotropin-releasing hormone in depression and post-traumatic stress disorder. Peptides 22:845-851.

Koob GF, Heinrichs SC (1999) A role for corticotropin releasing factor and urocortin in behavioral responses to stressors. Brain Res 848:141-152.

Laugero KD (2001) A new perspective on glucocorticoid feedback: relation to stress, carbohydrate feeding and feeling better. J Neuroendocrinol 13:827-835.

Lightman SL, Young III WS (1988) Corticotropin-releasing factor, vasopressin and pro-opiomelanocortin mRNA responses to stress and opiates in the rat. J Physiol (Lond) 403:511-523.

Ma XM, Aguilera G (1999) Transcriptional responses of the vasopressin and corticotropin-releasing hormone genes to acute and repeated intraperitoneal hypertonic saline injection in rats. Brain Res Mol Brain Res 68:129-140.

Ma XM, Lightman SL, Aguilera G (1999) Vasopressin and corticotropinreleasing hormone gene responses to novel restraint in rats adapted to repeated restraint. Endocrinology 140:3623-3632.

Maj M, Turchan J, Smialowska M, Przewlocka B (2003) Morphine and cocaine influence on CRF biosynthesis in the rat central nucleus of amygdala. Neuropeptides 37:105-110.

Makino S, Schulkin J, Smith MA, Pacak K, Palkovits M, Gold PW (1995) Regulation of corticotropin-releasing hormone receptor messenger ribonucleic acid in the rat brain and pituitary by glucocorticoids and stress. Endocrinology 136:4517-4525.

McNally GP, Akil H (2002) Role of corticotropin-releasing hormone in the amygdala and bed nucleus of the stria terminalis in the behavioral, pain modulatory, and endocrine consequences of opiate withdrawal. Neuroscience 12:605-617.

Mocchetti I, Ritter A, Costa E (1989) Down-regulation of proopiomelanocortin synthesis and beta-endorphin utilization in hypothalamus of morphine-tolerant rats. J Mol Neurosci 1:33-38.

Pages N, Orosco M, Fournier G, Rouch C, Hafi A, Gourch A, Comoy E, Bohuon C (1991) The effects of chronic administration of morphine on the levels of brain and adrenal catecholamines and neuropeptide $\mathrm{Y}$ in rats. Gen Pharmacol 22:943-947.

Pinelli A, Trivulzio S, Spezia R (1998) Effects of tizanidine administration in precipitated opioid withdrawal signs in rats. Drug Alcohol Depend 50:81-88.
Richard D, Lin Q, Timofeeva E (2002) The corticotropin-releasing factor family of peptides and CRF receptors: their roles in the regulation of energy balance. Eur J Pharmacol 440:189-197.

Rivier C, Vale W (1983) Modulation of stress-induced ACTH release by corticotropin-releasing factor, catecholamines and vasopressin. Nature 305:325-327.

Rivier C, Rivier J, Mormede P, Vale W (1984) Studies on the nature of the interaction between vasopressin and corticotropin-releasing factor on adrenocorticotropin release in the rat. Endocrinology 115:882-886.

Sawchenko PE, Li H-Y, Ericsson A (2000) Circuits and mechanisms governing hypothalamic responses to stress: a tale of two paradigms. Prog Brain Res 122:61-78

Schmidt ED, Binnekade R, Janszen AW, Tilders FJH (1996) Short stressor induced long-lasting increases of vasopressin stores in hypothalamic corticotropin-releasing hormone $(\mathrm{CRH})$ neurons in adult rats. J Neuroendocrinol 8:703-712.

Schulkin J, McEwen BS, Gold PW (1994) Allostasis, amygdala, and anticipatory angst. Neurosci Biobehav Rev 18:385-396.

Shalev U, Grimm JW, Shaham Y (2002) Neurobiology of relapse to heroin and cocaine seeking: a review. Pharmacol Rev 54:1-42.

van Dijken HH, de Goeij DCE, Sutano W, Mos J, de Kloet ER, Tilders FJH (1993) Short inescapable stress produces long-lasting changes in the brain-pituitary-adrenal axis of adult male rats. Neuroendocrinology 58:57-64.

Viau V, Soriano L, Dallman MF (2001) Androgens alter corticotropinreleasing hormone and vasopressin mRNA within forebrain sites known to regulate activity in the hypothalamic-pituitary-adrenal axis. J Neuroendocrinol 13:442-452.

Walker DL, Davis M (1997) Double dissociation between involvement of the bed nucleus of the stria terminalis and the central nucleus of the amygdala in startle increases produced by conditioned versus unconditioned fear. J Neurosci 17:9375-9383.

Wardlaw SL, Kim J, Sobieszcyk S (1996) Effect of morphine on proopiomelanocortin gene expression and peptide levels in the hypothalamus. Brain Res Mol Brain Res 41:140-147.

Williams F, Cair XJ, Elliott JC, Harrold JA (2004) Anabolic neuropeptides. Physiol Behav 81:211-222.

Woldbye DP, Klemp K, Madsen TM (1998) Neuropeptide Y attenuates naloxone-precipitated morphine withdrawal via Y5-like receptors J Pharmacol Exp Ther 284:633-636. 